\title{
THE DISCURSIVE SUPPRESSION OF WOMEN: FEMALE EVILS AS THE VILLAINS OF THE MOTHERHOOD NARRATIVE
}

\author{
Leyla Önal
}

\begin{abstract}
This article focuses on the discursive construction and control of female sexuality and sexual activity, which simultaneously lead to the definition of women as inherently evil and to their suppression. This process is reinforced through a "motherhood narrative" inaugurated by a number of discourses, wherein female evils play the role of the villains, either as evil women or as anthropomorphised female beings that harm the mother or the unborn/newborn baby. The role of the "female evil", a universally occurring archetypal motif, is to steal, kill or harm the child or the mother during pregnancy, labour, or puerperium. This motif is taken into account particularly in the framework of discourses that can be termed as medico-religious. Case studies of female evils are given as examples in the article, with a focus on the motherhood narrative and medico-religious discourses. This focus provides an insight to the way in which female evils pertain to the suppression of women within a more general framework. Female evils appear as necessary constructs of the aforementioned discourses to be able to control female sexual activity and the motherhood related fears of women, especially through the internalisation of control and through shaping the relationship of women with other women.
\end{abstract}

Key words: Albastı, Ancient Mesopotamia, birth, childbed fever, Lamaštu, Lamia, Lilith, medico-religious discourse, motherhood, sorcery, strigae, witchcraft.

\section{THE DISCURSIVE SUPPRESSION OF WOMEN: FEMALE EVILS AS THE VILLAINS OF THE MOTHERHOOD NARRATIVE}

The female body has been seen in various cultures as a site of contamination, causing impurity also for others, through socially unacceptable forms of contact. Therefore, the female body, as the site of abjection ${ }^{1}$, served as the basis of the symbolic constructs which associate women with specific forms of "evil". The abjection of the female body is most overtly manifest in the processes of menstruation - conceptualised as unclean in many cultures ${ }^{2}-$ and labour, as the essential processes of female reproduction. Paradoxically, female repro- 
duction, as the subject of numerous discourses from medicine to law and religion, incorporates both fear and fascination.

This article focuses on the construction of a "motherhood narrative" around this fear and fascination related to female reproduction. This narrative, as the subject of numerous discourses, is important in terms of illustrating how women's suppression takes place in a narrative which includes phenomena typically belonging to the "feminine realm" and how other women as symbolised in the form of "female evils" can serve as the agents for further facilitating this suppression. Among these discourses related to the motherhood narrative, the medico-religious ones are of particular interest since they associate female evils both with bodily and mental illnesses within the narrative. The female evils play a dual role in the narrative, both in terms of representing the repressed parts of female sexuality - as the fearful side of women - and also the fears of women related to motherhood.

The first part of the article provides an explanation of the concepts of motherhood narrative and female evils. The second part includes examples of the case studies of female evils and looks at their existing similarities in function in spite of their contextual specificities. The third part examines the ways in which the motherhood narrative is constructed through medico-religious discourses in a way to serve the suppression of women, with the help of the female evils. The final part deals with the suppression of women within a more general framework, through discourses which facilitate the differentiation not only between men and women, but also between women and other women.

\section{THE NARRATIVE AND THE VILLAINS}

Although the numerous discourses related to reproduction in general, and female reproduction in particular, can be to a large extent culture specific, they nevertheless serve to construct female sexuality and control female sexual activity; either in essentialist or in constructivist terms, or both. The control of female sexual activity and thus female reproduction is important as the means of securing the continuation of the bloodline in particular and society in general.

These discourses ascribe women with an exchange value ${ }^{3}$ concomitant with the motherhood narrative. The latter is necessary for the maintenance of the social order where the role of women in the division of labour within the public and private spheres is defined usually in terms of concepts related to motherhood. With the same token, motherhood is considered the proper role for women, and being a mother is presented as both a socially and individually desirable goal. This desire has to be fulfilled by women in a legitimate, and 
thus, permissible way. Therefore, motherhood ${ }^{4}$, as used here, does not merely refer to being a mother but specifically to "motherhood in a legitimate form".

The "motherhood narrative" can be seen as a universal fiction which represents motherhood as an unequivocal goal for women. This narrative includes phenomena such as conception, infertility, menopause, pregnancy and pregnancy loss, the health of the mother and the baby in general, and childcare; phenomena which typically remained in the feminine realm. Thus, the motherhood narrative is used as an operational concept which includes all the aforementioned phenomena in the feminine realm, but excludes the unspeakable aspects of femininity which slightly correspond to "women as sexual agents ${ }^{5}$ " or the "dark side of the feminine".

Within a context where female sexuality belongs to the realm of bodily impurity and discursive silence, the motherhood narrative comes to be associated only with pregnancy, labour and childcare through the conciliation of female sexual activity. Thus, motherhood becomes the sole - asexual - site of female activity, which, on the one hand represents the fulfilment of the female desire, and on the other hand defines this site as separate or even purified from female sexual activity. Thus, the motherhood narrative in this sense tells the story of female reproduction, but not of female sexuality.

The phenomena which typically belong to the "feminine realm" of the motherhood narrative, for the most part remained untouched by men. Once female sexuality remains under control and the motherhood narrative takes place within a framework of legitimacy, men do not play any major part in this narrative at all (Zingsem 2005: 283). Nevertheless, the feminine realm is not free from the mechanisms of construction and control, with one exception: within this realm, these mechanisms operate according to different dynamics.

The feminine realm is intriguing in this sense, since it seems like a site of action for women, but at the same time, it also serves for the activity of female evils. Therefore, the feminine realm of the motherhood narrative can act as a site of suppression for women, where the agents of the suppression are other women.

The motherhood narrative differentiates between mothers and other women in a way that legitimate mothers are valorised and put in a position not only as different from, but also as superior to other women. The position of legitimate mothers can also serve for loathing other women, as in the case of adulteresses (illegitimate mothers), murderous midwives, barren or childless women and bad mothers. These are "other" women who represent the dark side of the feminine and the fears of women related to motherhood. These two elements are symbolised in the form of female evils which play the role of the villain in the motherhood narrative and facilitate the suppression of women. 
This suppression operates through a twofold process: first, the birth related fears of women have to be replenished, and then, the dangers inherent in the narrative - like pregnancy loss or postnatal death - have to be exorcised and kept outside in order that the former start working as mechanisms for the internalisation of control.

The female evils constitute the exorcised elements of the narrative through playing the role of the villain. The villain of the motherhood narrative is necessarily a female evil, whose task is to steal, kill or harm the unborn/newborn baby or the mother during pregnancy, labour, or puerperium. Mothers and their unborn/newborn babies are threatened by a female evil, which can be any kind of harmful being incontrovertibly conceptualised as female.

The idea of the female evil works in two ways: either the perceived harmful supernatural and magical forces or beings are presented as female, or the actions of women can be associated with harmful magic and sorcery. Therefore, the female evil can be a woman embedded in a discourse which sees evil as an innate characteristic of women - the dark side of the feminine, or it can be an evil force or being, represented as female, or appearing in the form of a woman.

Within a discourse which defines women only in their relation to men - as daughters, wives and mothers - the female evil simply connotes "other" women, who escape this bind and thus, evade societal control mechanisms. These women are disruptive for the system since their role in society is defined as being illegitimate mothers and barren or childless women. Although the female evils can be mothers themselves, their status as mothers is always illegitimate. They are the antitheses of proper women, being condemned to be seen as evil and malevolent.

In short, the female evil is a harmful woman or an anthropomorphised female being, playing the role of the villain of the motherhood narrative instead of playing her proper role as an obedient woman. Female evils represent the repressed sexuality and fears of proper women, and facilitate the suppression of the latter by the attribution of an innate evil to women.

\section{WHERE ARE THE FEMALE EVILS?}

Female evils of the motherhood narrative can be found within a spatial and temporal variance. The first known examples which are going to be presented in the article appeared in ancient Sumer, Assyria and Babylonia. These in turn have been articulated into Rabbinic literature ${ }^{7}$ and found their way into various other settings. However, there are a number of additional examples that 
appear in significantly distant cultures. Due to the distance of the cultures, the possibility of cultural influence through migration ${ }^{8}$ (Hurwitz 2009: 46, 134, 223 ) is ruled out, an observation which can lead to the conclusion that the female evil is a universally occurring archetypal ${ }^{9}$ motif. The examples of this motif include Baba Yaga of the Russian and Slavic peoples, Hariti of the Buddhists of India, Kishimogin of Japan, Black Annis of English folklore and Langsuir of Malaysia among many others. All these examples from varying geographies represent the cultural transformations of the same archetypal motif, which is known as Lamaštu in Mesopotamia, Lamia, Empusa, Mormo and Gello in Greece and Rome, Strix, Striga or strigae and the witches of early modern Europe, and Albastı or Al-karısı in contemporary Anatolia.

These latter examples are chosen in a subjective manner to represent the variations of the motif within a limited geographical proximity, keeping the possibility of cultural interaction and historical reciprocity ${ }^{10}$ open. The examples illustrate a continuity within which the first example comes from Ancient Mesopotamia and the last from contemporary Anatolia. The middle examples are from Ancient Greece and Rome and early modern Europe, which, altogether, form a general picture of the female evil of the motherhood narrative. The final example is peculiar in the sense that it illustrates not only the existence of female evils even in the contemporary world, but also points out the traces of the medico-religious discourses that had been used for defining their role.

Although these female evils appear in a multiplicity of forms and pertain to their cultural specificities, they also have analogous traits and present functional contingencies. The given examples are seen as variations of the same archetypal motif, which represent both the transformation of the female evils on the one hand, and the preservation of the functional contingencies on the other. These examples constitute merely descriptive categories which should not be regarded as overall in-depth studies of the presented female evils.

Each example is unique in character and they point out that in spite of the spatial and temporal variances, the motherhood narrative is endowed with both fearsome and miraculous elements which open up a role for the female evils.

Lamaštu is the example from ancient Mesopotamia, and can also be found in Assyria, Sumer and Babylon. Although she was known as Lamaštu in Assyria, she probably originated from the Sumerian Dimme or Lamme. The concept of this deity spread also to Syria. The Hurrians probably introduced her to Anatolia (Leick 1998: 109). 
Lamaštu appeared in various cuneiform tablets which presented her in association with disease and difficulty in childbirth (George \& Finkel 2000: 252-253). Lamaštu was defined either as a demon, goddess or monster (Ann \& Imel 1993: 336), and in all of these forms she was identified as a female being. In Sumer, she was a lion-headed goddess who coveted humans and their children. She was also described as having donkey's teeth, bare breasts and a hairy body, blood-stained hands with long fingers and nails, and the clawed, talon-like feet of a bird (Hurwitz 2009: 43; Leick 1998: 110).

In Assyria Lamaštu was a demon-goddess who taunted the sick and infected children with the plague and killed them. As Charles Russell Coulter and Patricia Turner (2000: 285) point out, she also appeared as a winged animal, or was depicted as a woman with wild hair and bare breasts.

The traits ascribed to Lamaštu included slaying infants and unborn babies, causing harm to mothers in general and expectant mothers in particular, sucking men's blood and eating their flesh and bringing disease and death. She was generally held responsible for miscarriage and cot-death and represented the danger of infant and child mortality (Leick 1998: 110). She taunted the sick and carried the plague around by means of feeding poisonous milk to babies from her breasts and by using her talons to tear the flesh of humans. "Bring me your children to suckle, I shall be their nurse" was her call (Leick 1998: 110). She could slide in and out of houses at will, terrifying the inhabitants. She was known to have a violent temper, and when in rage, she could slay domestic animals with her bare hands.

To protect herself and the child from Lamaštu, the expectant mother had to wear a protective amulet made of bronze, or metal. Another method of protection was to keep stone plaques with inscribed incantations in and around the house. Gwendolyn Leick (1998: 110) notes that “...many charms and masks have been excavated in the ancient towns which used to hang by doorways in the hope of keeping her at bay."

Lamia is the Greek equivalent of Lamaštu (Hurwitz 2009: 43). The demonic Lamia, whose name means 'devourer' (March 1999: 229), appeared in classical Greece and Rome. Lamia was the personification of the land of Libya, and she also was the land's queen. She was a very beautiful woman and attracted the attention of Zeus ${ }^{11}$, to whom she bore children. When Zeus's jealous wife Hera ${ }^{12}$ found out the affair, she killed Lamia's children every time Lamia gave birth. The loss of her children drove Lamia insane, and she retreated to a solitary cave (Grimal 1990: 236). She became jealous of mothers who were more fortunate than herself. In despair and seeking vengeance, she started to steal and kill the children of other women (March 2001: 451). Her cruelty - or grief - 
started to reflect upon her and she became monstrous with distorted features. She was depicted as a creature with the body of a snake and the head of a beautiful woman (Hurwitz 2009: 43). Siegmund Hurwitz notes that even today there is a belief in Greece that if a young boy, especially a handsome one, whistles on the beach at midday or midnight, the Lamia of the sea rises and wants to take him as her husband. If the boy refuses, she kills him (2009: 43).

Later, the Lamia figure of classical Greece and Rome took the plural form lamiae, referring to beautiful ghastly women. They attracted men, used up their energy, drank their blood and ate their flesh. As Robert Bell (1991: 312) notes they were the equivalents of the contemporary conception of vampires. Another example of lamiae comes from the stories of Europe in the Middle Ages. Hans Peter Broedel (2003: 104) refers to these stories which mentioned beings called lamiae, appearing as women who slipped into houses, killed children and conducted other gruesome deeds. These creatures had the faces of people but their bodies were of beasts.

Other accounts of the presence of lamiae in the Middle Ages include Johannes de Janua's 13th century work Catholicon, in which Janua explains the etymology of lamiae (Broedel 2003: 104). The name lamiae had conventionally been delivered from laniāre meaning 'to rend'. The work also mentioned about lamiae that they had the habit of tearing children into bits. It has also been added that old women snuck into houses pretending lamiae were there, killed infants, tore them into pieces and resurrected the bodies.

The lamiae of the Middle Ages were described as demons or spirits. Therefore, even if they could not consume children's flesh in their incorporeal form, they occasionally killed children to punish their parents. Female spirits who attached themselves to little children in order to suck their blood were also called lamiae (Grimal 1996: 296). Lamiae entered houses at night and oppressed sleepers, moved infants from place to place or molested them, drank human blood and caused serious illness. Other names and forms of the Greek Lamia were Empusa, Mormolyceia (known as Mormo) and Gelo (Bell 1991: 312; Grimal 1996: 296).

Empusa was a female Graeco-Roman spirit which haunted the night, a bogeywoman, with one donkey's foot and the other made of brass (Grant \& Hazel 1993: 20). She was thought to assume various shapes and sometimes vanish altogether (Luck 1999: 130). She was one of Hecate's ${ }^{13}$ companions and Hecate used the empusae to frighten foreign travellers. Empusa was believed to be able to assume various shapes and appeared particularly to women and children (Grimal 1990: 136). At the same time she was known to take the form of a beautiful young woman to lure men and suck their blood dry until they were 
dead. To escape from her, one had to insult her loudly, which would make her flee shrieking (Grimal 1996: 146) or "squeaking like the devil" (Luck 1999: 130). She was a night-witch figure, who had the habit to "...feed on young and beautiful bodies, because their blood [was] pure and strong" (Gordon 1999: 217). Hurwitz (2009: 44) noted about the Empusa that, like Lamia, she lives in the fairy tales and folklore of modern Greece.

Mormo was a Greek demoness whose name means 'frightful' (March 1999: 261). She was believed to bite little children, especially the naughty ones and make them lame. Mormo was a hideous she-monster who attacked little children and used nursery-bogeys to frighten them into good behaviour (March 2001: 514). She even killed and ate her own offspring (Hurwitz 2009: 44). Like Empusa, Mormo was a shape-shifter, who could take up the form of a young woman to attract men and consume their blood and flesh.

Gelo of Ancient Greece appeared as Gelou in Hebrew, and as Gallu or Gello in Babylonian, Sumerian and Semitic languages (Coulter \& Turner 2000: 185, 189) and as Gello, Gylo or Gyllou in Graeco-Byzantine mythology (Hurwitz 2009: 41). Gelo was an ogre living on the island of Lesbos, being the tormented soul of a maiden who had died young and kept returning to earth to steal children (Grimal 1996: 170).

Strix ${ }^{14}$ was a Graeco-Roman child-stealing, bloodsucking enchantress (Hurwitz 2009: 44-45) which also originated from Lamia. She later took the form of the strigae of the Middle Ages which were malevolent bird-like creatures (Broedel 2003: 104). Hurwitz (2009: 46) mentions that Striga may have been derived from Hystera, the demon who spells danger for the mother's womb ${ }^{15}$. Hurwitz (2009: 44) also states that this figure lives on in contemporary Greek popular culture together with Neo-Greek folk tales and legends.

Strigae of the Middle Ages were dangerous birds that flew by night searching for infants to nourish themselves by sucking their blood and devouring the flesh. Hurwitz (2009: 44) states that strigae, in folk tradition, are enchantresses who "...fly at night in the guise of birds to the cradles of children and suck their blood”. According to Grimal (1996: 427) strigae, in popular belief, were winged female demons with talons like those of birds of prey who fed on the blood and entrails of little children.

Francis King (1987: 20) notes about the strigae that during the early periods of Christianity, human servants of Satan were believed to be strigae and have powers very similar to those attributed to the witches ${ }^{\mathbf{1 6}}$. They were birds of prey with talons capable of tearing the flesh and possessed breasts of women which were filled with poisonous milk like the Assyrian Lamaštu. They offered 
milk to babies left lying unprotected in their cradles. Thus, they were often seen as the cause of postnatal death. Moreover, they sometimes flew to sleeping men and drained their blood and energy while having intercourse with them.

To point out the conventionality of the belief in strigae, Broedel (2003: 168) gives the example of the 6th century Pactus Legis Salicae. The Pactus ordered that a striga - the singular form of strigae - which was proven to have eaten a man was liable to a fine of 8000 denarii. It has also been stated by King (1987: 21) and P. G. Maxwell-Stuart (2004: 221/illustr. 4) that strigae were often identified with the screech-owl and commonly denoted a witch that could change her shape and fly. King (1987:21) adds that “...it was probably for this reason that as late as the 16th century a common English term for a man who was wasting away as the result, so it was believed, of witchcraft, was referred to as "owl blasted"."

The witch, as a generic category for women with ill-repute who conduct evil deeds, is closely connected to the lamiae and strigae. The witch is a common figure in folklore and fairy tales, usually depicted as an ugly and elderly woman. During the Middle Ages, many women were accused of being witches and were held responsible for threatening expectant mothers and newborn children besides other malevolent acts. According to Broedel (2003: 3) 15th century Europe was the landmark of the witches' chronicle and thousands of women were accused of being witches, tortured and sentenced to death.

Broedel states that "...prior to the 15 th century, people spoke in terms of heretics, of maleficium, of monstrous female spirits - the lamiae and strigae, but not of a single composite category of "witch"." (Broedel 2003: 3) However, by the midst of the 16th century, scholars generally agreed upon the definitions of "witch" and "witchcraft", definitions which drew upon, but were clearly distinguished from older categories. Witchcraft was described as a phenomenon which was explicitly gendered and highly sexual in nature (Broedel 2003: 20). The phenomenon of witchcraft appeared in a setting where, according to Marianne Hester, gender relations were an integral part of the Christian political ideology, and there was a “...sexual double standard with female sexuality presented as inferior to that of men..." (Hester 1996: 292). Women were seen as inferior to men since they were "...perceived as more likely to be sexually deviant than men because women were by definition (like Eve in the Garden of Eden) sexually deviant" (Hester 1996: 296; Roper 1994: 18). This discourse presented women as inherently evil and was used for blaming them for various ills. 
Since women were by definition more sexually deviant, the practice of witchcraft was seen as resulting from the insatiable sexual desire of women (Hester 1996: 292). The libidinous witches cast spells on men in order to make them unable to engage in benign sexual intercourse with their wives. Thus, the victims became the subjects of the witches' sexual desires. Gareth Roberts, in a similar fashion like that of Hester, argues about the sexual nature of witches that "a metaphoric extension of the idea that witchcraft is seductive, pleasurable and unmanning is the use of this nexus of ideas for purposes of Protestant propaganda in the sixteenth- and seventeenth-century England." (Roberts 1996: 201)

Even though every woman could be accused of being a witch at the time, the most susceptible women were the midwives according to Broedel (2003: 7). The midwives were commonly accused of being witches because of their highly skilled knowledge in herbalism, medicine and other practices particularly related to reproduction and the female body such as contraception and their role in assisting the labour process. All these tasks being performed by midwives denoted the loosening of the power over female sexuality and put the midwives with their inexplicable powers in a suspicious position. Thus, the most formidable kind of witch was the midwife-one, who specialised in killing and eating un-baptised children. Broedel states that the midwife-witches were the worst of all their kind “...for they kill[ed] infants both in the womb and at birth, and [were] even in the habit of stealing, vampire-like, into homes to drink the blood of children." (Broedel 2003: 27) Witches also had the ability to fly (Broedel 2003: 183) and change shape in some accounts, which can also be interpreted as an indication of the homology between witches and the night-flying strigae.

However, the witch-trials in Germany during the 17th century indicated a shift in the attention concerning the deeds and behaviour of witches. According to Roper, these trials were particularly focused on "relations between mothers, those occupying maternal roles and children" and they typically included “...accusations brought by mothers, soon after giving birth, against women intimately concerned with the care of the child...” (Roper 1994: 202) Therefore, Roper identifies the lying-in-maid as another category of women frequently accused of being witches, since they were concerned with the care of the child right after birth. Although the midwife-witch represents the fears of men about loosening their control over the labour process, the lying-in-maid represents the fears of the mother, and a shift of attention from sexuality to motherhood.

This focus on motherhood is illustrated by the witch-trials, where the activities of the witches were mentioned as including harming the baby or the mother by pressing, or pushing them down during labour. This activity was referred to in German as drücken, a verb denoting the use of witchcraft in at 
least three different contexts: “...to describe the way the Devil forces one woman to do evil, the smothering of an infant, and a mysterious kind of oppression felt by the woman who has just given birth." (Roper 1997: 210)

Although during the period men were also accused of being witches, the significant majority of witches were women. As stated by Marianne Hester (1996: 291), with reference to Christina Larner, "witch hunting is woman-hunting or at least the hunting of women who do not fulfil the male view of how women ought to conduct themselves."

Lilith, as another example of the motif, originated from Ancient Mesopotamia and found her way into Jewish mystical traditions. Her name also appeared in various cultures, including the Sumerian, Babylonian, Assyrian, Jewish and Arabic (Hurwitz 2009: 32). It has been stated by Coulter and Turner (2000: 285) that Lamia as a child-slaying demon can be seen as the forerunner of Lilith of the early Hebrews. Lilith is closely associated with the lamiae and strigae who brought death to newborn babies and fed on human blood and flesh (Calmet 1993: 67).

The name Lilith first appeared in the Sumerian Epic of Gilgamesh where she was referred to as a creature that flew to desolate places, and haunted the deserts after her shelter was destroyed by the hero Gilgamesh (Patai 1968: 27). Later, Lilith and incantations against her appeared on the Nippur Bowls ${ }^{17}$ of Babylonia. The texts on these incantation bowls about Lilith indicated that she attached herself to sleeping humans and acquired rights of cohabitation through this attachment as a result of which she generated demonic offspring (Lesses 2004: 357-358; Levi 1995: 23).

In the post-Biblical period, Lilith appeared as the first wife of Adam, and they both were created from dust, earth or clay (Black Koltuv 1986: 22; Levi 1995: 21; Zingsem 2005: 35). Adam and Lilith could not be happy together since they had a dispute about the manner of their intercourse. Lilith told Adam "I will not lie beneath you"18 (Cantor 1998: 19), and she pronounced the ineffable name of God $\left(\mathrm{Yhwh}^{\mathbf{1 9}}\right)$, became a she-devil and acquired wings ${ }^{20}$. She flew away to the Red Sea, the place which was regarded as the realm of demons and other mischievous creatures (Levi 1995: 22) ${ }^{21}$. Adam felt lonely when Lilith left and asked Yhwh to bring her back. Yhwh sent three angels, Snwy, Snsnwy and Smnglf ${ }^{22}$ (Scholem 1974: 357) to persuade Lilith. After listening to their message, Lilith refused to return, and the angels cursed her because of her disobedient reply. The punishment brought upon her was the death of one hundred of her offspring each day. Moreover, the angels made Lilith swear an oath saying that wherever she saw the angels' name on an amulet or image, she would do no harm to the baby. 
It was a common practice to protect women from Lilith during childbirth by putting amulets over the bed, on the door of the room and the four walls of the room. According to Gershom Scholem, amulets, portraying not only the names but also the forms of the three angels, Snwy, Snsnwy and Smnglf, were printed even as late as in the 18th century (1974: 358). Likewise, Scholem points out that from the 16th century onwards, it has been a common belief that if a child was laughing while asleep or alone, Lilith was playing with him or her (Scholem 1974: 358). Dom Augustine Calmet (1993: 67) also notes that the belief in Lilith was apparent in the practice of writing "Adam, Eve. Be gone from hence lilith", in the corners of the room where a woman just delivered her baby.

The Hebrew name Lilith, which appears in the Bible; in Isaiah 34:14 of the Old Testament (Black Koltuv 1986: 11), is translated as the 'screech-owl' or 'night monster' (Ann \& Imel 1993: 336). Although the stories about Lilith are multiple, her role in the multiplicity of these stories is enmeshed in the common themes of killing unborn/newborn babies and infants, flying at night, sneaking into houses and disturbing humans while they sleep, taking the shape of a beautiful woman and having intercourse with men, then sucking their blood and eating their flesh. Lilith also managed to prevent the birth of children by causing barrenness, miscarriage, or complications during childbirth.

Lilith was sometimes used in a multiple form, referring to a group of succubi. Raphael Patai (1968: 212) states that succubi were jealous of the human mates of the people to whom they attached themselves. Because of their jealousy, the succubi hated the children born of ordinary human wedlock and tried to harm them. It is not clear why Lilith was bound to harm babies even before she had been cursed by the angels. Her reaction can nevertheless be regarded as an upheaval against her punishment or as an act of jealousy. Probably, she sucked the blood of human infants, plagued and strangled them for avenging the death of her own offspring. According to Raphael Patai (1968: 229), Lilith remained in the imagery of the Jewish tradition as a child killer up until the 19 th century, and continued her existence in folklore later on. Black Koltuv (1986: 11) states that although there is no further explicit mention of her by name except in Isaiah 34:14 as quoted above, “...these images exist in the modern psyche" ${ }^{23}$. It is still a custom - the roots of which may have been long forgotten - that the sleeping child should be tapped three times on the nose to avoid dangers from Lilith when she is caught playing with the child.

Albastı, or Al-karısı probably had its roots in the animistic religions of the peoples of contemporary Anatolia who migrated there from various geographical locations. Together with contemporary Anatolia, the belief in Albastı was common among the Turkic people, and the name appeared as Albastı or Al- 
karısı in the Middle and West Asia, as Albız in the Ottoman writings, as Albıs among the Uranha-Tuba Turks, as Almıs among the Altai Turks, and as Abast among the Yakut Turks (Çay 1983: 53). Albastı was also adopted by the Armenian, Georgian and Caucasian cultures (Çobanoğlu 2003: 124-125); likewise, Orhan Acıpayaml (1974: 11) mentions that evidence can be found in various historical documents from Ancient Egypt, Ancient Greece and Sumer that there have been beings corresponding to the Al-spirit.

The inhabitants of Anatolia may have borrowed Albastı from Egypt, Hittite and Sumer (Eyuboğlu 1998: 122), cultures in which the belief in spirits attacking women or babies, during and after childbirth, was common. Since the folk tradition of Anatolia has always been reflected upon the amalgamation of the belief systems of the various peoples who ruled parts of Anatolia throughout the ages, the descendants of these peoples contributed to contemporary Anatolia's multicultural population, and the traces of their beliefs can still be found across the region in a multiplicity of forms.

The belief that a puerperal woman and her newborn baby could be harmed by beings, which can be referred to as spirits or jinn ${ }^{24}$, is apparent in Anatolian folk tradition. This condition of being harmed, or the being which causes the harm is called Albastı or Al-karısı, which are the most common names among various others. Albast is a female being, unambiguously indicated by her other common name Al-karıst, in which the second part means "woman" or "wife" (Doğan 1981: 529). Al-karısı simply means "red hag"25, where kart is the vulgar form of "wife, old woman, hag" (Redhouse 2004: 536) ${ }^{26}$.

Albast in some occasions is described as a spirit, and can also be a jinn, fairy or demon which appears in many disguises, from a giant to a spider or a witch-woman. This witch-woman can be a tall blonde, or a woman with scattered black hair. In her accounts, she can have both a zoomorphic appearance and also a bestial one, wearing a red shirt. It is also believed that Albastı can alter her shape into various forms of a human-animal creature. Despite of all the possibilities, Albastı most often appears as a witch-woman (Acıpayamlı 1974: 75-76).

Regardless of the form that she takes, Albastı attacks women and children in order to feed herself or her own offspring. For this purpose, she tears off the lungs of her victims and suffocates them. The belief in Albastı can take two major forms: Albast is either used as the name of a being, or as the outcome of the encounter with that particular being. This indicates that the two beliefs exist in a conjoined form, and that Albast is both a being and the name of an illness. Thus, it can be said that Albastı, which had once been a formless spiritual force, transformed into an illness and then turned into a being as the personification of that illness in a female form (Acıpayaml 1974: 119). 
In correspondence with the being, the Turkish idiom al basmak refers to the belief in folk tradition according to which the evil spirit al treads on the puerperal woman. When the $a l$-spirit strikes, the woman turns red, which in fact is a condition caused by puerperal fever (Püsküllüoğlu 2003: 87). In medical terms, al refers to erysipelas, puerperal fever (İz 1992: 17), and also to childbed fever, whereas the verb form al-basmak means 'to get puerperal fever' (Redhouse 2004: 31), experienced by puerperal women due to the lack of proper sanitary conditions. The state of reddening and suffocation, which are believed to be caused by Albastı, are actually the results of common medical complications. The puerperal mother or the newborn baby may turn red due to fever or lung inefficiency. The fever known as puerperal or childbed fever is caused by an infection within the uterus, causing a febrile state resulting from the infection of the endometrium and septiciemia following delivery (Gennaro 1979: 1130). If the infection involves the bloodstream, it can develop into puerperal sepsis, which is a serious form of blood poisoning, as a result of which the whole body may enter into an inflammatory state to fight the infection, with symptoms of redness and swelling.

Just like the mother, the baby would also turn red as a result of the attack of Albastr. The medical name given to this condition is postnatal asphyxia and atelectasis, or, in other words, the respiratory distress of the newborn (Gennaro 1979: 1086). When struck by $A l$ the mother or the baby would feel as if being under a heavy load, unable to breathe and talk; a symptom which is common to both medical conditions.

Albastı strikes only puerperal women, and newborn babies who are younger than 40 days. This belief also has a medical explanation, since 42 days or six weeks is the period required for the uterus to return to its normal size after birth (Stedman 1995: 1464; Martin 1994: 549). After this period, the involution of the uterus is complete.

Paralleling the various appearances of Albast, the measures taken for protection may vary across regions, however, every variant includes the common element of protecting the mother and the baby by way of the colour red. The most common practice is to tie a red scarf around the head of the mother and to cover the baby with a similarly coloured cloth for forty days. Other practices include using red ornaments on pillows, a red blanket as a cover, or wrapping a red ribbon around the head. To protect the puerperal woman from Albast and possible troubles, ropes are stretched out across the room over the woman's head, and onions, mirrors and the Quran are hung on these ropes (Gökbel 1998: 94). In case of an encounter with Albast, an immediate warning should be made, and a nearby person should hold the mother or the baby tight when being attacked by Albastr. To make them come to their senses and fight against 
Albast, the mother or the baby should be shocked by a sudden action or noise - if they do not struggle, Albast takes over and brings them to the point of suffocation (Gökbel 1998: 94; Çay 1983: 54). In some areas a ritual which includes the singing of holy songs is performed to prevent suffocation; a lamb's lung may be offered to Albast to take instead of the lung of the mother or the baby (Çay 1983: 54). Moreover, the guests are not allowed to hold a newborn baby, and the same ban is set for menstruating women in case the infant is less than forty days old. The visitors should be given a red drink called lohusa şerbeti (Boratav 1973: 187; Çobanoğlu 2003: 125) which is a red herbal potion made by boiling various herbs in sugary water.

Iron $^{27}$ is the protective element against Albastı, and it should be placed in the room of the mother and the baby. Moreover, making noises with iron or other tools made of metal make Albastı flee, since she is known to be afraid of the noise of iron or metal, as well as the material itself. Another belief is that Albastı hides and dwells in barns, haylofts, and desolate places, ruins, in the proximity of water sources, rocks and fountains. These places should be approached only after certain protective words or phrases have been uttered.

It is also a common practice in some parts of contemporary Anatolia that experienced older women or midwives assist the mother and the baby during labour and puerperium and take care of their well-being. Midwives are usually not medical specialists but elderly women whose knowledge proceeds from experience in matters of childbirth in particular and female sexuality in general; as a rule, they have a number of children themselves. Sometimes they prepare special herbal medicines known as kocakart ilact (Redhouse 2004: 536), translated as 'folk remedy', 'hag's medicine' or 'witch's brew'; the know-how about the ingredients of which had traditionally been passed on to generations of women.

\section{MEDICO-RELIGIOUS DISCOURSES AND THE REPRODUCTIVE BODY: ALL WOMEN ARE SORCERESSES}

The given examples of female evils illustrate certain commonalities in crosscultural and cross-historical perspectives, presenting recurrent themes around which the concept of the female evil circles in relation to the motherhood narrative. Although some examples simultaneously carry out the double function of representing devious female sexuality and the fears inherent in the motherhood narrative, eventually, the former function tends to lessen and the focus becomes reduced to the role in harming the baby or the mother, especially in the cases of the witches and Albast. 
Besides being malevolent creatures and harming the mothers and babies, female evils are associated with sorcery and witchcraft, and have the ability to appear in many forms, transform themselves or to change shape. Catharina Raudvere (1996: 47) notes that special attention can be paid to female shapeshifters because "by contrast to many of the male characters with the same abilities, the women act almost exclusively out of greed, envy, depravity, corruption and unrequited love." This difference can be explained with reference to Frymer-Kensky who states that the myths of female revenge may have had "...less to do with actual female behaviour than with the projection of male feelings about the woman (mother)..." (1992: 204). These feelings combine both fear and fascination as noted in the beginning of the article.

The fears are manifested in a number of discourses related to female reproduction which cannot be understood separately - Holly Tucker presents the "...basic observation that conception and childbirth are at the core of the human experience; procreation is never "just" a biological phenomenon. The reproductive body is shared in virtually infinite ways by diverse cultural discourses that are always in dialogue with one another." (Tucker 2003: 15) Therefore, the suppression of women goes beyond the control of the female sexual activity and female reproduction, and disseminates through discursive practices as parts of “...the larger pattern of dominance-submission, which includes political, economic, and social, as well as theological dimensions." (Osiek 1985: 103)

Among all these numerous discourses, the medical and religious ones are particularly important in terms of talking about the motherhood narrative and the role of female evils. The medical discourse, in the sense we understand it today, constructs and controls the corporeality of the body in general and the female body in particular. The religious discourse works together with the former to extend the processes of construction and control to the psyche. They mutually rationalise each other and exist in a co-dependent manner. Together, in a form that can be referred to as medico-religious, these discourses cover both the mundane and the sacred elements of existence, where the body and the psyche are perceived in a conjoined form.

The medico-religious discourses brought protection from female evils into focus, through the use of rituals and incantations. These included protective measures against female evils, since the latter were seen among the major causes of complications such as miscarriage, postnatal death, childbed fever and various other ill-nesses.

The medico-religious discourse, wherein these female evils played their particular roles, can provide a better insight in order to understand the function of the given discourse in relation to a more general framework. The no- 
tion of medico-religious discourse can be best exemplified by looking at Ancient Mesopotamia, where medical and religious discourses were not quite separate. Within this context, the internal mechanisms of the body could only be explained with reference to outside forces such as various supernatural beings. Illness was perceived as an intrusion coming from outside and entering the body in some fashion, an understanding which intertwined the fields of medicine and religion. The people of Ancient Mesopotamia believed that various beings, such as demons and evil spirits, could be found everywhere and they could affect human life. These beings in general and female evils in particular, were seen as the causes of disease, illness and death. In some cases, they operated as personifications of certain diseases ${ }^{28}$.

There are numerous medical texts ${ }^{29}$ from Ancient Mesopotamia that brought into light the ways of conceptualising illnesses, containing various prescriptions for certain diseases. JoAnn Scurlock (2006: 19) presents 352 "prescriptions" from Ancient Mesopotamia that had been used for treating physical, mental and spiritual symptoms, apparently associated with harmful "ghost" activity. The prescriptions included offerings, libations, figurines, ritual burial and dispatch, encirclement, amulets, fumigants, bandages, salves, potions, washes and suppositories among various others.

In Ancient Mesopotamia, there were two kinds of causes of illnesses, both of which could be associated with the activity of harmful beings. The first cause of illness or any kind of trouble was the punishment sent by higher forces, i.e. the deities, as a result of the offences committed by the person. These offences covered a wide range of acts, from disrupting the social order, to willingly or unwillingly breaking the taboos (Biggs 2005: 3). Another possible and more common source of physical or mental problems was sorcery. There were incantations which mentioned outsiders, specifically foreign women, as the instigators of sorcery. A variety of demons and other beings which usually had some partial human characteristics were mentioned in the aforementioned medical texts, on the basis of their relation to sorcery. The texts mentioned that the victims of these beings have been "seized" or "stroked" and that the beings caused the illness and death of their victims. Scurlock points out that these illnesses or harmful activities involved a number of medical symptoms which are related to women and children, such as “...barrenness, excessive vaginal discharges, difficulty in giving birth, puerperal fever and the like, or infantile afflictions, or jaundice, gall bladder, urinary tract problems..." (Scurlock 2006: 19) among various other symptoms.

Although the causes of illnesses were seen as supernatural, bodily illnesses have been diagnosed and treated on the basis of practical know-how. In Ancient Mesopotamia, medicine grew out of a folk tradition which can be referred 
to as herbal medicine in today's terms. This tradition included the use of plants and plant products, minerals, animals and their products as the basic ingredients of medications. Herbal medicine was practiced by both men and women. However, women possessed particular knowledge which remained largely unknown to men, primarily concerning the "invisible" or "unseen" - thus incomprehensible - parts of the female body and female sexuality. This knowledge had been passed on to generations of women in an oral form.

Robert Biggs (2005: 1) states that "female problems" related to pregnancy and childbirth had often been addressed in medical texts of Ancient Mesopotamia. He also underlines that the illnesses of babies and children were detailed in the chapters of the omen collection whereas the same diseases and illnesses were not mentioned at all in the medical texts (Biggs 2005: 9). This final statement can be seen as an indication that female evils were seen among the causes of illnesses and death of babies and children.

Labour was considered largely as a "female problem". Biggs (2005: 9) notes that in spite of the numerous prescriptions for physicians to treat a woman with complications after childbirth, there was no indication in these texts that physicians assisted in the delivery. Instead, assistance was provided by a midwife called šabsūtu who was probably aided by a female relative. Although these texts were predominantly medical, they frequently combined medical and magical treatment ${ }^{30}$, both of which were provided by men (Biggs 2005: 1). While the role of male practitioners of medicine and magic was clear, the role of the midwives or šabsūtu assisting the labour process remained quite vague.

Other examples of the medico-religious discourse of Mesopotamia included inscriptions on numerous incantation bowls and texts of Rabbinic literature, featuring the names and depictions of female evils and identifying the protective elements against them. Rebecca Lesses has examined the publications of 154 incantation bowls and notes that almost one half of these incantations mentioned Lilith or liliths at least once (2004: 354). About one third mentioned other female evil spirits and approximately ten percent referred to evil human women. In addition to these, the formulae on several bowls specified groups of women of some sort, particularly family members, as enemies who have cursed people (Lesses 2004: 355). In addition, having studied the Babylonian Talmud ${ }^{31}$, which represented the major religious discourse of early monotheism in Ancient Mesopotamia, Lesses mentions that the Babylonian Talmud, in the legal discussion about sorcery, states that "most women are sorceresses" (2004: 343). She also points out that many other texts of Rabbinic literature, including the Torah $^{32}$ as a fundamental text, explicitly referred to women as sorceresses and sorcery was conceptualised as a feminine practice. This was accepted as a general fact about women and constituted the basis of the discourse that most 
women "...naturally, in the ordinary way of the world, are sorceresses" (Lesses 2004: 351). It has also been stated by Lesses (2004: 354) that the incantation bowls and Rabbinic literature had a lot in common with the beliefs concerning sorcery, although the incantation bowls, unlike the texts of Rabbinic literature, did not contain explicit statements about women's relation to sorcery, they nevertheless provided a gendered view about sorcery. Lesses notes that many incantations and amulets, belonging to both to the pre-monotheistic and monotheistic periods of the area, named the client of the incantation or the practitioner by his or her mother's name, instead of the father's name. This can be seen as an indication of the association of sorcery with women "at the ideological level" (Lesses 2004: 363).

The examples from the medico-religious discourses of the Graeco-Roman world illustrate a similar view about women as that of the rabbis. Lesses, having excessively examined the works of the writers of antiquity and late antiquity, states that these examples also depicted women as sorceresses. She presented the examples of Circe in the Odyssey, Medea in Euripedes and Seneca, Dido in Virgil's Aeneid, Erictho in Lucan's Pharsalia, and several witches in The Golden Ass by Apuleius. Lesses concluded that the association of women with sorcery in the Graeco-Roman world was an ideological act, which practically served as a means of control. Seeing women as sorceresses validated the exclusion of women from normal means of power. Furthermore, the accusation of women with the practice of sorcery provided a "stick with which women could be beaten". Since the mechanisms of sorcery were inexplicable and the practice of sorcery was a secretive act, the accusation of being a sorceress was almost impossible to refute (Lesses 2004: 366). This point is strengthened by Daniel Ogden's argument - in relation to the curse tablets ${ }^{33}$ of Ancient Greece and Rome - that women were often present even in tablets that appear to address disputes entirely between men, and that “...individuals in the tablets are often identified not by their father's name (patronymic), as was usual and proper in the ancient world, but by their mother's name (matronymic)" (Ogden 1999: 61), a form of addressing that may have been borrowed from Early Egyptian and Babylonian spells.

However, there was a major difference between the incantation bowls of Ancient Mesopotamia and the Graeco-Roman curse tablets, and the Rabbinic literature. The bowls and tablets were made for both men and women, mainly for protection against female evils or for lifting the curse of the latter. They reflected the fears of both men and women concerning the well-being of the family in general, and the health of their children in particular. At the same time, they also presented the primary concerns and needs of women in life: health, pregnancy, childbirth, children's health, sexual anxieties and the fear 
of demonic attack (Lesses 2004: 367; Hurwitz 2009: 113). While women were more concerned about issues related to the "feminine realm" men had different concerns in relation to female evils. Men were particularly concerned about sexual protection ${ }^{34}$ from the latter.

Conversely, Rabbinic literature was produced by a certain group of men, including the rabbis or other scholars and intellectuals. They produced texts primarily for each other or for other men. Rabbinic literature expressed male anxieties and fears which were particularly sexual in nature. Rabbis who led a secluded life were less concerned about the issues of daily life and more focused on power relations and the maintenance of their dominant position in society. Men, as rabbis, were the legitimate holders of supernatural powers, while women, as sorceresses, had illegitimate claims towards similar powers. As a result, women with supernatural powers or with powers of sorcery were regarded as threatening for rabbis' position. Rabbis did not hold an unchallengeable power in Ancient Babylonia (Lesses 2004: 368) and feared that women with the power of sorcery could contest them.

The infamous position of women as sorceresses was a part of the overall Rabbinic project that defined gender and labelled women as the source of evil deeds. This understanding of women as inherently evil is not any different from the case of the witches of early modern Europe, where women, like Eve, represented temptation and the fall. Such labelling served to rationalise the suppression of women in society which, within the Rabbinic project, included discarding women from the public realm and the crumbling of their ability to claim knowledge.

The women who were involved in medico-religious practices (e.g. midwives) came to be placed in a suspicious position since the phenomena these women were dealing with, and also their practices were "invisible" and "unseen" - and could thus evade male control. Due to their suspicious position, these women were accused of being sorceresses or witches, and became the female evils of the motherhood narrative.

\section{WOMEN AS “OTHERS”: THE DISCURSIVE SUPPRESSION OF WOMEN}

As it can be observed from the given examples, there is an inherent bias to associate only female evils with the motherhood narrative. The phenomena within the "feminine realm" of the narrative remained out of men's concern but not of control - even at the symbolic level. Hurwitz notes that the attitude of "...man towards the feminine is, at bottom, nothing more nor less than an 
expression of his deep-seated fears and his uncertainty of womankind. At the same time, behind these fears must also lie a certain fascination... it is both fear and fascination, which, with the utmost difficulty, fashion the man's debate with the feminine." (Hurwitz 2009: 184, 197)

Therefore, we can see that this debate with the feminine is centred on discourses which represent women as "radically other" (Frymer-Kensky 1992: 31 ) in comparison to men. For example, women were seen by the Greeks as inherently so different from men that they "...spoke of a genes gynaikon, a "race of women", as if women were an entirely different species of men" (FrymerKensky 1992: 203). A number of examples of female evils are born out of this context, which also influenced later discourses.

This worldview is not specific to Ancient Greece but represents the number of contexts from which the examples of the female evil are drawn. The GraecoRoman images of Father Zeus/Jupiter ${ }^{35}$ which have been influenced by the imagery of Ancient Mesopotamia have in turn governed the shaping of the modern/Western psyche ${ }^{36}$. William Phipps (1989: 1) presents the further observation that "those sharing the Judeo-Christian heritage have generally assumed that the gender of the deity is masculine." This line of thought, which is also in line with the Muslim, tends to see the deity/Father/Creator/Lord/God/ Elohim ${ }^{37} /$ Allah $^{38}$ as a man, and portrays the latter within discourses also dominated by men.

Frances Klopper (2002: 423) states that "if we see God as a man or more like a man or more properly named in male language, we tend to think of men as more like God and women less like God" as women are associated with the fall. A worldview is created which sees the difference between men and women as an irreconcilable one and as stated by Daniel Boyarin “...this opposition lies at the root of every discursive practice” (1998: 117). These discursive practices by and large put women not only in a different but also in an inferior position, an argument which can be best followed by Judith Butler's (1993: 2) statement that "discourse produces the effects that it names."

This kind of a representation in which women are given an opposing and usually subordinating set of attributes ${ }^{39}$ in contrast to men also affected the perception of their role in reproduction. The medical texts from Ancient Mesopotamia constitute an example which illustrates that men were believed to be the only essential actors of reproduction as providers of semen, and this was seen as the sole instigator of conception. Since the internal dynamics of the female body were not observable for the people of Ancient Mesopotamia, it was believed that the woman's body had to be possessed and impregnated by the male agent. Frymer-Kensky (1992: 48) noted that "the role of males in reproduction had been understood at least since the domestication of animals (in 
the Near East, around $9000 \mathrm{BC}$ ). But the ovum is a very recent discovery, and biology, until early modern times, considered the male sperm to be the sole agent in engendering the child."

This view illustrates that the "feminine realm" of the motherhood narrative does not necessarily depict the active agency of women. Rather, the female body is conceptualised as a passive means of reproduction and serves a role similar to that of a carrier. The understanding about women's passive role in reproduction in Ancient Mesopotamia was paralleled also in the GraecoRoman world, where it was believed that "the mother is no parent of that which is called her child, but only nurse of the new planted seed that grows... a stranger, she preserves a stranger's seed..." (Frymer-Kensky 1992: 204)

Paradoxically, the role of men in the motherhood narrative was quite limited except their role of providing semen as the necessary means of reproduction (Hurwitz 2009: 110). Although paradoxical, this situation was in line with the bias of seeing motherhood as a solely female enterprise and put the responsibility of the dangers inherent in the motherhood narrative specifically on the shoulders of women. The presented examples of medico-religious discourses further strengthen this understanding by showing that the labour process was assisted by other women or midwives instead of male practitioners.

At the same time, reproductive heterosexual activity was valorised in Ancient Mesopotamia, in a fashion not quite different from the contemporary valorisation of motherhood. Reproduction was seen - as today - to be the main function of women in society and "...the woman was considered the eager recipient of the baby" (Frymer-Kensky 1992: 121). Women had to be seen as eager recipients since they became valuable and respectable only within the motherhood narrative, as opposed to barren or childless women, or illegitimate mothers, who constituted typologies for female evils as opposed to legitimate mothers.

The same discourses shaped the relation of women to each other and reinforced the difference between women and mothers: mothers as valuable and respectable females being opposed to "other" women, who basically serve no function. A vivid example of this difference is evident in witch-trials of the 17 th century Germany where "...the accusations were made by women who experienced childbirth and their most common type of target was a post-menopausal, infertile woman who was caring for the infant." (Roper 1997: 204) This argument is further strengthened by Malcolm Gaskill who, referring to the stereotypes concerning witches, states that they were usually “...female, economically marginal and rarely had living husbands” (1996: 258). In this sense, mothers constituted the category of "proper women" who were "...expected to remain mostly at home and to leave their houses only on legitimate errands" (Frymer-Kensky 1992: 28). On the other hand, there were "other" women, 
who were not occupied with the usual social responsibilities of a woman, but were free from encumbrances and “...dangerous, fearsome and threatening because of [their] freedom" (Frymer-Kensky 1992: 29). These "others" were usually portrayed as temptresses - a stereotype which is still intact - who were not bound to a home or man, further emphasising the difference between women and mothers. "Other" women take the form of the female evils in the motherhood narrative and regardless of their portrayal as mothers themselves or sometimes as excessively fertile - as in the case of Lilith - they could generate only "demonic offspring" because of their illegitimate sexual activity. In short, they appear as the antitheses of "proper women" - their sexuality cannot be kept under control, they pursue whomever they wish, seduce men and lead them astray from their families, beget illegitimate offspring and kill the legitimate ones. In this sense, the female evils as the villains of the motherhood narrative represent the "untamed" part of women.

These women are malevolent and they trespass the suppressing boundaries. They cannot possibly be virtuous, thus, they also pose a castration threat to men ${ }^{40}$. This threat is posed by female evils in two ways: either they produce illegitimate offspring who cannot secure the continuation of the bloodline, or they kill the legitimate heirs. They can also cause impotence and infertility, or kill the men.

In either way, they serve as a means of distinguishing a "forbidden" category of women as Leach (1989: 45) notes with reference to Levi-Strauss that the control of female sexuality "...implies a capacity to distinguish between women who are permitted and women who are forbidden." The female evils represent the "forbidden" category of women who are not the virgins to be married and not the ones to become mothers. With their insatiable sexuality, the female evils are innately barred of being legitimate mothers in a motherhood narrative which excludes female sexuality.

Female evils, as antitypes of proper women, are anarchic figures who are not constrained by law, convention or sanity (Lesses 2004: 369). They are almost always the ones who disturb society.

\section{CONCLUSION: AND THEY WILL KEEP ON WHISPERING}

While motherhood is presented both as a goal for women and as the fulfilment of the female desire, it also involves a great burden for women. If a woman miscarries, gives stillbirth, or gives birth to a child with a certain disorder, it is possible that she becomes labelled as unfaithful, cursed or bewitched, or in any case, the legitimacy of the child may be questioned. Women always have to 
defend their respectability by staying within the boundaries defined for "proper women". They are suppressed into a defensive position by various discursive practices, of which the medico-religious one is an example. Within this framework, women's sexuality should remain unambiguous and under control. Otherwise, they can be ridiculed, labelled, outcast and even punished by both men, and other women.

Therefore, the fear is not only about the physiological complications inherent in the motherhood narrative, but also about their social implementations, all of which together create a great anxiety for women.

Today, the belief in sorcery and witchcraft has declined and modern medicine and psychiatry replaced medico-religious discourses in treating bodily and metal problems. With the same token, while the physiological complications in the motherhood narrative became the subject of modern medicine, the apparent symptoms of the aforementioned anxieties in women became the subject of psychiatry. These symptoms do not take the form of female wickedness anymore, and are instead defined as disorders, such as tokophobia (the fear of giving birth), hysteria and postpartum depression. The cause of women's "inexplicable" behaviour had to be rationalised even in the absence of a psychoanalytical discourse and at the times of repressed female sexuality, and thus the fears of women were projected onto the female evils. Although these evils have ceased to be regarded as the villains of the motherhood narrative, it is still the case, in Roper's words (1997: 212) that “...women today may attempt to use the defence of post-partum psychosis to argue that they were not legally responsible for crimes committed during the first few weeks after giving birth."

Female evils are not considered to be the major causes of "female problems" or the carriers of the plague in the contemporary world. However, this is a relatively recent development. As pointed out by Judit Blair (2005) our understanding of the cause of some diseases had been transformed only during the past hundred years, together with the knowledge of pathogenicity. This knowledge substantiated the existence of germs together with finding out their role in the transmission of diseases. These events facilitated the replacement of rituals and incantations by therapeutics and hygiene became the new means of protection.

Although it may seem that germs and bacteria have assumed the role which formerly belonged to female evils - carrying the plague and feeding poisonous milk to babies - they nevertheless continue their existence in the psyche and cultural imagery of today. They will keep on representing the "dark feminine" which still poses a castration threat as the uncontrollable, untamable, powerful side of women and also a double bind which still causes the discursive suppression of women. 


\section{NOTES}

1 Abjection is used here in a sense corresponding to that of Julia Kristeva (1982: 1), whereby abject means both a "tempting and condemned" being, which is simultaneously the object of desire and what that desire rejects.

2 There are complicated taboos placed on women in cultures as far apart as the Middle East and North America that saw menstruation as filthy and dangerous (Pollack 1997: 135; Black Koltuv 1990: 14). Rachel Biale states that there is a taboo on menstruating women in the world at large “...since many cultures share the same basic psychological components: fear of bleeding, discomfort with genital discharge, and bewilderment especially on the part of men, at the mysterious cycle of bleeding and its connection to conception and birth." (Biale 1984: 147)

${ }^{3}$ Luce Irigaray (1985b: 170) states that "the society we know, our own culture, is based upon the exchange of women... The passage into the social order, into the symbolic order, into order as such, is assured by the fact that men, or groups of men, circulate women among themselves, according to a rule known as the incest taboo."

4 The reference here is an "institution of motherhood" which is different from "motherhood as a personal and psychological process". The latter refers to "the potential relationship of any woman to her powers of reproduction and to children" (Fuchs 1985: 129) whereas the former refers "...to the mechanism aimed at ensuring that that potential - and all women - shall remain under male control" (Fuchs 1985: 129).

5 Women in the motherhood narrative are not seen as sexual agents but conceived within a fantasy which slightly corresponds to that of a "virgin-mother". Leach (1971: 107) states about such fantasies that "from many sources we learn of legends, traditions, ritual practices which seem to imply a belief that women may sometimes be pregnant by means other than insemination by a human male."

6 This is an analogy with the "dark side of the moon" since the moon represents feminine energy (Zingsem 2005: 92; Hurwitz 2009: 21). Correspondingly, the dark side represents the repressed aspects of the feminine, with a focus on female sexual energy and sexual activity. It also includes the destructive attitudes and the "murderous rage" of women as representations of the premenstrual syndrome, the rejection of motherhood, mother's possessiveness and hostility, jealousy and competitiveness towards other mothers (Black Koltuv 1986:10, 85; Zingsem 2005: 283, 287 288; Fuchs 1985: 131).

7 This term is applied to texts produced by the rabbis in the late antiquity, regarding the centrality of the Torah (Neusner et al. 1999: 949).

8 Hurwitz (2009: 46) also states that child-stealing, bloodsucking beings which could appear as seductive women can be found in the mythology of almost all peoples. He also notes that there were myths in which both aspects occurred simultaneously.

9 According to Jung (1958: 148f) this is "an irrepresentable factor, a disposition which starts functioning at a given moment in the development of the human mind and arranges the material of consciousness into definite patterns." In Jungian psychoa- 
nalysis, the "archetype" is the secret, collective, symbolic language that all of us recognise (Wolf 1998: xi).

${ }^{10}$ West discusses (1995: vii) that there is an evidence for Mycenaean trade and colonisation in the Orient, and for oriental trade and colonisation in the Aegean and Greece. There are also Semitic motifs in the Greek iconography and mythology and that some Greek names also had Semitic origins and origins in Mesopotamian mythology.

${ }^{11}$ Zeus is regarded as the greatest god of the Greek pantheon. He was essentially the god of light, of clear skies as well as of thunder (Grimal 1990: 453).

${ }^{12}$ Hera was the greatest of all the Olympian goddesses. She married Zeus in a formal wedding ceremony (Grimal 1990: 181).

${ }^{13}$ Hecate is a Graeco-Roman goddess, who originated from Lamaštu, and is originally chthonian and malevolent (West 1995: 316).

${ }^{14}$ Hurwitz (2009: 47) states that "in zoology, owls are commonly classified as Strigiformes. A subdivision consists of owls in the strict sense of the term, or Strigidae. To this group belongs the screech owl or Strix, known for catching small mammals."

${ }^{15}$ Hystera is a place, ground or dwelling, shaped like a cave or a womb (Irigaray 1985a: 243).

${ }^{16}$ Hurwitz (2009: 47-48) looked at different languages to trace particular similarities. He notes that "in Italian, the word strega means something akin to an old evil woman or witch, who is in league with the devil. In Old French, the word is estrie and means 'a vampire-like creature'. The Portuguese parallel, estria, means 'witch'. She corresponds to the Spanish bruja... But in all languages, so to speak, the word means a witch on the one hand and a predatory night owl on the other... But in non-Romanic languages, too, the striga is well-known. In the Balkans, her name is strygoi."

17 These bowls were found in the ruins of houses in a Jewish settlement in Nippur, corresponding to the southern part of Babylonia. Similar inscriptions have been found in different areas of the Middle East. Although the date of the manufacture of these bowls has not yet been definitely established, Hurwitz (2009: 90) notes that they might have been produced in the 6 th or 7 th centuries BC. The inscriptions on the bowls include Aramaic magic texts, which reflect the Jewish tradition of Babylonia of the time. These texts were published in 1913 (Hurwitz 2009: 90).

${ }^{18}$ Hurwitz, elaborating on the issues underlying this story notes that "the wife's demand for equality and autonomy must have appeared highly threatening to the male consciousness moulded by the spiritually-patriarchal cultural canons... [which not only holds good] for the consciousness of the Jewish man but is also typical of the whole of Western culture in the Classical period, the Middle Ages and, partially, in Modern times. It holds good equally for Christendom, Islam and Judaism." (Hurwitz 2009: 183)

${ }^{19} \mathrm{Yhwh}$ is the Biblical proper name of God. It consists of the letters yud, heh, vav, heh, which constitute the Tetragrammaton. It is interpreted as denoting eternal existence. It is the holiest of names and is never pronounced (Werblowsky \& Wigoder 1997: 278). 
${ }^{20}$ Black Koltuv (1986: 22) interprets this story as the claim of Lilith for equality with Adam since they were both created from dust or earth. She refused the activity and dominance of Adam and sought the freedom to move, act, choose and determine herself. Black Koltuv interprets Lilith as the quality in a woman that refuses to be bound in a relationship.

21 "And Lilith left Adam and went to seek her own place

And the gates were closed behind her and her name was

stricken from the Book of Life." (Sherman 1998: 355)

${ }^{22}$ The names of these angels may vary according to authors, as Senoi, Sansenoi and Semangloph in Hurwitz (2009: 120) or as Sanvai, Sansanvai and Semangelof in Black Koltuv (1986: 103).

${ }^{23}$ Lilith is a lively figure in today's popular culture especially in music and visual arts. Rivlin (1998: 390) gives a list of works and artists inspired by Lilith or bearing her name in the afterword to the book Which Lilith? Feminist Writers Re-Create the World's First Woman. Probably the most famous of these examples from popular culture is the Lilith Fair, a music festival held by female artists only, during the summers of 1997-1999 and revived in 2010.

${ }^{24}$ The jinn are an order of spirits lower than angels in Islamic mythology. They are said to have the power of appearing in human and animal forms and to exercise supernatural influence over man. They are mostly the servants of Iblis (the Devil) (Bonnerjea 1927: 123).

${ }^{25}$ Hurwitz (2009: 213) also mentions that Lilith, in the Zohar, was also portrayed as having red hair and a scarlet dress, in a similar fashion like that of Albast. This colour also has psychoanalytic and symbolic implications which are not going to be discussed in detail.

${ }^{26}$ Both the aforementioned names Albastı and Al-Karısı can be divided into two parts: The adjective $A l$ constitutes the first part which means 'red colour, vermilion, crimson, flame scarlet' (İz 1992: 17; Redhouse 2004: 31) and is explained as the colour of blood. The second part is the verb 'basmak' which means 'attack suddenly, overpower, press, tread on, flood, over-flow, to descend on, cover' (İz 1992: 57; Redhouse 2004: 97). The combination of these two can be translated as 'to redden' or 'to get struck by red'.

${ }^{27}$ Bonnerjea (1927: 120) states that the jinn, the general category of beings to which Albastı belongs, dread iron so much that even the name of this metal acts as a charm against Albast. In European folklore, witches are also kept at bay by iron instruments.

${ }^{28}$ Albastı is a contemporary example of such personifications.

${ }^{29}$ The earliest archaeological evidence includes medical texts dated around $2000 \mathrm{BC}$, from the Third Dynasty of Ur and written in Sumerian. The largest portion of these texts is Neo-Assyrian (Biggs 2005: 1). There are also numerous Babylonian medical texts from the Hittite capital of Khattusha near the modern village of Boğazköy in central Anatolia (contemporary Republic of Turkey) which are closely linked to the fewer number of Mesopotamian texts from the 2nd millennium. According to Robert Biggs (2005: 1) there are several word-for-word parallelisms of these texts, suggesting that the texts from Neo-Assyrian times may reflect the practices of nearly a 
millennium earlier. Although these texts present examples from Ancient Mesopotamia, parallelisms can be found between Mesopotamian medicine and the medical practice of Ancient Greece (Biggs 2005: 17).

${ }^{30}$ These treatments are the medical asûtu and the magical āšipūtu. It was apparent in the medical texts that the physician called as $\hat{u}$ and the magician called šipu, both male, had been working side by side on the same cases (Biggs 2005: 1). The practices of the $a s \hat{u}$ and the āšipu both included the usage of amulets and incantations for protection from harmful beings.

31 Talmud is the Hebrew word for 'study'. It is the most important work of the Oral Torah (Unterman 1991: 194).

${ }^{32}$ Torah is the Hebrew word for 'teaching'. It is one of the central concepts of Judaism, which may refer to the Ten Commandments, the Hebrew Bible, or the whole of Jewish Tradition in its widest sense (Unterman 1991: 200).

${ }^{33}$ Ogden (1999: 3-4) states that there are 1.600 currently known tablets from various sites, most of which are written in Greek, and another significant part in Latin. The earliest batch of 22 Greek tablets is from the Greek colony of Selenius in Sicily, dating from the early 5 th century BC. The majority of all known curse tablets were found in Attica, ranging throughout the classical, Hellenistic and imperial periods. The phenomenon of curse tablets flourished between the 2 nd and 5 th centuries BC (Ogden 1999: 61).

${ }^{34}$ These female evils attached themselves to men and getting rid of them was possible only through a ritual of divorce. They acted as if they were married to men and acquired rights of cohabitation, while they prevented men from having benign sexual intercourse with their lawful wives (Hurwitz 2009: 100), or caused impotency.

${ }^{35}$ Jupiter is the sovereign divinity of the Romans, originally a sky-god who has supreme power over other gods and men. He was identified with the Greek Zeus, and adopted Zeus's mythology as his own (March 2001: 403).

${ }^{36}$ The most famous example of this influence is the image of a bearded Creator painted by Michelangelo on the ceiling of the Sistine Chapel in the Renaissance period.

${ }^{37}$ Elohim is a plural form, but it is used in a singular form when referring to the God of Israel. The proper name Yhwh is not used in order to "avoid taking the name of the Lord in vain" (Werblowsky \& Wigoder 1997: 278).

${ }^{38}$ Allah is the Arabic name for God. The name was known in pre-Islamic Arabia as the head of the pantheon among polytheists and as the name for God among Arabicspeaking Christians and Jews. With the advent of Islam, Allah was defined as "the One”, eternal, neither born nor bearing and not having an equal (Newby 2002: 26).

${ }^{39}$ Men are seen as the creators of culture, they are rational, trustworthy, strong, active, vigorous, honourable, courageous, combative, independent, dominant, heroic and sadistic. Women, on the other hand, are seen as close to nature, they are emotional, sentimental, weak, grieving, passive, beautiful, alluring, protective, nurturing, dependent, submissive, cowardly, deceptive, confined, altruistic and masochistic (Black Koltuv 1986: 22; Fuchs 1985: 121).

40 They pose this threat because they represent the loss of domination and manhood (Hurwitz 2009: 220-221, 230). 


\section{REFERENCES}

Acıpayaml, Orhan 1974. Türkiye’de Doğumla İlgili Adet ve İnanmaların Etnolojik Etüdü. [An Ethnological Study of Birth Related Traditions and Beliefs in Turkey.] Ankara: Sevinç Yayınları.

Ann, Martha \& Imel, Dorothy Myers 1993. Goddesses in World Mythology:A Biographical Dictionary. Santa Barbara: ABC-CLIO.

Bell, Robert E. 1991. Women of Classical Mythology:A Biographical Dictionary. California: ABC-CLIO.

Biale, Rachel 1984. Women and Jewish Law: The Essential Texts, Their History \& Their Relevance for Today. New York: Schocken Books.

Biggs, Robert D. 2005. Medicine, Surgery, and Public Health in Ancient Mesopotamia. Journal of Assyrian Academic Studies, Vol. 19, No. 1, pp 1-19.

Black Koltuv, Barbara 1986. The Book of Lilith. Lake Worth: Nicolas-Hays.

Black Koltuv, Barbara 1990. Weaving Woman: Essays in Feminine Psychology from the Notebooks of a Jungian Analyst. Maine: Nicolas-Hays.

Blair, Judit 2005 From Demons to Germs. Studia Universitatis Babes-Bolyai - Theologia Catholica Latina, No. 2, pp. 111-121.

Bonnerjea, Biren 1927. A Dictionary of Superstitions and Mythology. London: Folk Press. Boratav, Pertev Naili 1973. Yüz Soruda Türk Folkloru: İnanışlar, Töre ve Törenler, Oyunlar. [Turkish Folklore in 100 Questions: Beliefs, Customs, Rituals and Games.] İstanbul: Gerçek.

Boyarin, Daniel 1998. Gender. In: M. C. Taylor (ed.) Critical Terms for Religious Studies. Chicago: University of Chicago Press.

Broedel, Hans Peter 2003. The Malleus Maleficarum and the Construction of Witchcraft. Manchester: Manchester University Press.

Butler, Judith 1993. Bodies That Matter. New York: Routledge.

Calmet, Dom Augustine 1993. Treatise on Vampires and Revenants: The Phantom World. Brighton: Desert Island Books.

Cantor, Aviva 1998. Lilith, the Woman Who Would Be a Jew. In: E. Dame \& L. Rivlin \& H. Wenkart (eds.) Which Lilith? Feminist Writers Re-Create the World's First Woman. Northvale: Jason Aronson.

Coulter, Charles Russell \& Patricia Turner 2000. Encyclopedia of Ancient Deities. London: McFarland \& Co.

Çay, Abdülhalûk 1983. Anadolu'da Türk Damgası. [The Turkish Imprint on Anatolia.] Ankara:T.K.A.E.

Çobanoğlu, Özkul 2003. Türk Halk Kültüründe Memoratlar ve Halk İnançları. [Supernatural Tales and Folk Beliefs in Anatolian Folk Culture.] Ankara: Akçağ Yayınlart.

Doğan, Mehmet 1981. Büyük Türkçe Sözlük. [Grand Turkish Dictionary.] Ankara: Birlik Yayınları.

Eyuboğlu, İsmet Zeki 1998. Anadolu İnançları: Anadolu Üçlemesi - 1. [Anatolian Beliefs: The Anatolian Trilogy - 1.] İstanbul: Toplumsal Dönüşüm Yayınları.

Frymer-Kensky, Tikva 1992. In the Wake of the Goddesses: Women, Culture, and the Biblical Transformation of Pagan Myth. New York: Macmillan. 
Fuchs, Esther 1985. The Literary Characterization of Mothers and Sexual Politics in the Hebrew Bible. In: A. Y. Collins (ed.) Feminist Perspectives on Biblical Scholarship. Atlanta: Scholars Press.

Gaskill, Malcolm 1996. Witchcraft in Early Modern Kent: Stereotypes and the Background to Accusations. In: J. Barry \& M. Hester \& G. Roberts (eds.) Witchcraft in Early Modern Europe: Studies in Culture and Belief. New York: Cambridge University.

Gennaro, Alfonso R. 1979. Blakinston's Gould Medical Dictionary. New York: McGrawHill.

George, Andrew R. \& Finkel, Irving (eds.) 2000. Wisdom, Gods and Literature: Studies in Assyriology in Honour of W. G. Lambert. Indiana: Eisenbrauns.

Gordon, Richard 1999. Imagining Greek and Roman Magic. In: B. Ankarloo \& S. Clark (eds.) Witchcraft and Magic in Europe: Ancient Greece and Rome. Philadelphia: University of Pennsylvania.

Gökbel, Ahmet1998. Anadolu Varsaklarında İnanç ve Adetler. [Beliefs and Traditions of Anatolian Varsaks.] Ankara: Atatürk Kültür Merkezi Başkanlığı.

Grant, Michael \& John Hazel 1993. Who's Who in Classical Mythology. London: J. M. Dent.

Grimal, Pierre 1990. The Concise Dictionary of Classical Mythology. Oxford: Basil Blackwell.

Grimal, Pierre 1996. The Dictionary of Classical Mythology. Oxford: Basil Blackwell.

Hester, Marianne 1996. Patriarchal Reconstruction and Witch Hunting. In: J. Barry \& M. Hester \& G. Roberts (eds.) Witchcraft in Early Modern Europe: Studies in Culture and Belief. New York: Cambridge University.

Hurwitz, Siegmund 2009. Lilith - The First Eve: Historical and Psychological Aspects of the Dark Feminine. Zurich: Daimon.

Irigaray, Luce 1985a. Speculum of the Other Woman. New York: Cornell University Press.

Irigaray, Luce 1985b. This Sex Which is not One. New York: Cornell University Press.

İz, Fahir 1992. The Oxford Turkish Dictionary. New York: Oxford University Press.

Jung, Carl Gustav 1958. A Psychological Approach to the Dogma of the Trinity. In: C. G. Jung Psychology and Religion: West and East. New York: Pantheon Books.

King, Francis X. 1987. Witchcraft and Demonology. London: Exeter Books.

Klopper, Frances 2002. Women, Monotheism and the Gender of God. In Die Skriflig, Vol. 36, No. 3, pp. 421-437.

Kristeva, Julia 1982. Powers of Horror: An Essay on Abjection. New York: Columbia University Press.

Leach, Edmund 1971. Genesis as Myth and Other Essays. London: Jonathan Cape.

Leach, Edmund 1989. Claude Lévi-Strauss. Chicago: University of Chicago.

Leick, Gwendolyn 1998. A Dictionary of Ancient Near Eastern Mythology. London: Routledge.

Levi, Primo 1995. Moments of Reprieve. New York: Penguin.

Lesses, Rebecca 2004. Exe(o)rcising Power: Women as Sorceresses, Exorcists, and Demonesses in Babylonian Jewish Society of Late Antiquity. Journal of the American Academy of Religion, Vol. 69, No. 2, pp. 343-376. 
Luck, Georg 1999. Witches and Sorcerers in Classical Literature. In: B. Ankarloo \& S. Clark (eds.) Witchcraft and Magic in Europe: Ancient Greece and Rome. Philadelphia: University of Pennsylvania.

March, Jenny 1999. Cassel Dictionary of Classical Mythology. London: Cassell.

March, Jenny 2001. Cassel Dictionary of Classical Mythology. London: Cassell.

Martin, E. A. 1994. Concise Medical Dictionary. New York: Oxford University Press.

Maxwell-Stuart, P. G. 2004. Witchcraft: A History. Stroud: Tempus.

Neusner, Jacob \& Avery-Peck, Alan J. \& Green, William Scott (eds.) 1999. The Encyclopedia of Judaism, Vol. II. Leiden: E. J. Brill.

Newby, Gordon D. 2002. A Concise Encyclopedia of Islam. Oxford: Oneworld.

Ogden, Daniel. 1999. Binding Spells: Curse Tablets and Voodoo Dolls. In: B. Ankarloo \& S. Clark (eds.) Witchcraft and Magic in Europe: Ancient Greece and Rome. Philadelphia: University of Pennsylvania.

Osiek, Carolyn 1985. The Feminist and the Bible: Hermeneutical Alternatives. In. A. Y. Collins Feminist Perspectives on Biblical Scholarship. Atlanta: Scholars.

Patai, Raphael 1969. The Hebrew Goddess. New York: Ktav Publishing House.

Phipps, William E. 1989. Genesis and Gender: Biblical Myths of Sexuality and Their Cultural Impact. New York: Praeger.

Pollack, Rachel 1997. The Body of the Goddess: Sacred Wisdom in Myth, Landscape and Culture. Massachusetts: Element.

Püsküllüoğlu, Ali 2003. Türkçe Deyimler Sözlüğ̈̈. [Dictionary of Turkish Idioms.] Ankara: Arkadaş Yayınları.

Raudvere, Catharina 1996. Now You See Her, Now You Don't: Some Notes on the Conception of Female Shape-shifters in Scandinavian Traditions. In: S. Billington \& M. Green (eds.) The Concept of the Goddess. London: Routledge.

Redhouse English-Turkish / Turkish-English Dictionary 2004. İstanbul: Sev Yayınları.

Rivlin, Lilly 1998. Afterword: Lilith Lives. In: E. Dame \& L. Rivlin \& H. Wenkart (eds.) Which Lilith? Feminist Writers Re-Create the World's First Woman. Northvale: Jason Aronson.

Roberts, Gareth 1996. The Descendants of Circe: Witches and Renaissance Fictions. In: J. Barry \& M. Hester \& G. Roberts (eds.) Witchcraft in Early Modern Europe: Studies in Culture and Belief. New York: Cambridge University

Roper, Lyndal 1997. Oedipus \& the Devil: Witchcraft, Sexuality and Religion in Early Modern Europe. London: Routledge.

Scholem, Gershom 1974. Kabbalah. New York: Dorset.

Scurlock, JoAnn 2006. Magico-Medical Means of Treating Ghost-Induced Illnesses in Ancient Mesopotamia. Leiden: Brill.

Sherman, Susan 1998. Lilith of the Wildwood, of the Fair Places. In: E. Dame \& L. Rivlin \& H. Wenkart (eds.) Which Lilith? Feminist Writers Re-Create the World's First Woman. Northvale: Jason Aronson.

Stedman, Thomas Lathorp 1995. Stedman's Medical Dictionary. Baltimore: Lippincott Williams \& Wilkins.

Tucker, Holly 2003. Pregnant Fictions: Childbirth and the Fairy Tale in Early Modern France. Detroit: Wayne State University Press.

Unterman, Alan 1991. Dictionary of Jewish Lore and Legend. London: Thames \& Hudson. 
Werblowsky, Zwi Raphael Jehudah \& Wigoder, Geoffrey 1997. The Oxford Dictionary of the Jewish Religion. New York: Oxford University.

West, David R 1995. Some Cults of Greek Goddesses and Female Daemons of Oriental Origin. Darmstadt: Verlag Butzon \& Bercker Kevelaer.

Wolf, Naomi 1998. Introduction. In: E. Dame \& L. Rivlin \& H. Wenkart (eds.) Which Lilith? Feminist Writers Re-Create the World's First Woman. Northvale: Jason Aronson.

Zingsem, Vera 2005. Lilith:Adem'in İlk Karısı. [Lilith: Adam's First Wife.] İzmir: İlya. 